627

Un38t 35

CS

US Army Corps of Engineers
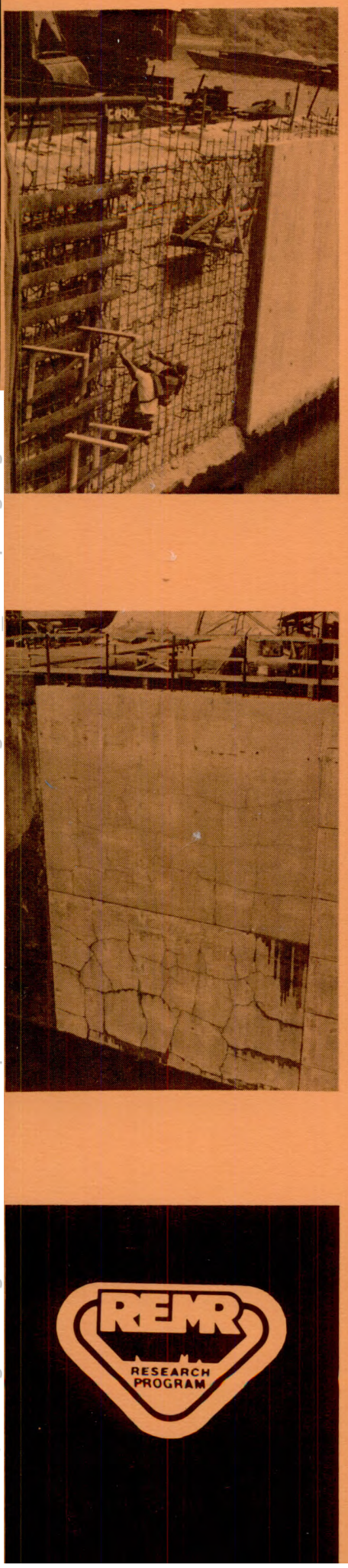

REPAIR, EVALUATION, MAINTENANCE, AND REHABILITATION RESEARCH PROGRAM

TECHNICAL REPORT REMR-CS-13

\section{REHABILITATION OF NAVIGATION LOCK WALLS: CASE HISTORIES}

by

\author{
James E. McDonald \\ Structures Laboratory \\ DEPARTMENT OF THE ARMY \\ Waterways Experiment Station, Corps of Engineers \\ PO Box 631, Vicksburg, Mississippi 39180-0631
}

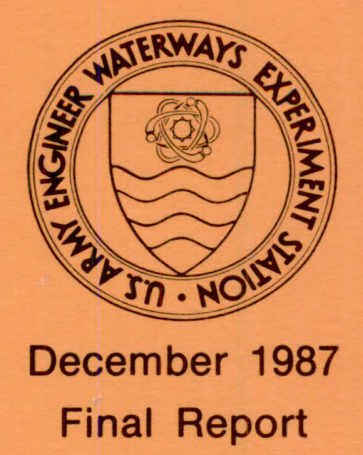

Approved For Public Release; Distribution Unlimited

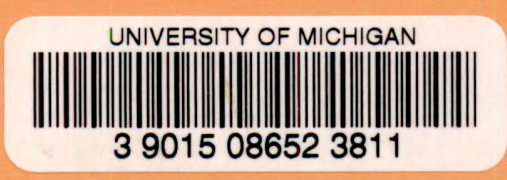
Prepared for DEPARTMENT OF THE ARMY
US Army Corps of Engineers
Washington, DC 20314-1000

Under Civil Works Research Work Unit 32273 